\title{
KONSTRUKCJA NORMATYWNA OBOWIĄZKU NASADZEŃ ZASTĘPCZYCH W POLSKIM PRAWIE OCHRONY PRZYRODY
}

\section{NORMATIVE CONCEPT OF REPLACEMENT PLANTING OBLIGATION IN THE POLISH NATURE CONSERVATION LAW}

\section{STRESZCZENIE}

Rozstrzygnięcie dotyczące nasadzeń zastępczych rozumianych jako zastąpienie usuwanych drzew lub krzewów innymi drzewami albo krzewami stanowi element zezwolenia na usunięcie drzew i krzewów, o zamieszczeniu którego orzeka uznaniowo organ wydający decyzję administracyjną. Zastosowana w Ustawie o ochronie przyrody konstrukcja normatywna odpowiada, ugruntowanej w doktrynie pra-

" Doktor nauk prawnych, adiunkt w Katedrze Prawa Ochrony Środowiska Wydziału Prawa i Administracji Uniwersytet Mikołaja Kopernika. 
wa administracyjnego, koncepcji zlecenia, stanowiącego klauzulę dodatkową aktu administracyjnego, na mocy której adresat tego aktu obciążony zostaje dodatkowym obowiązkiem administracyjnoprawnym. Przyjęcie, iż, wynikający z zezwolenia na usunięcie drzew lub krzewów, obowiązek nasadzeń zastępczych stanowi zlecenie w znaczeniu przyjętym w doktrynie prawa administracyjnego, prowadzi do dwóch zasadniczych wniosków: 1) niedopełnienie obowiązku nasadzeń zastępczych nie ma bezpośredniego wpływu na skuteczność (obowiązywanie) zezwolenia na usunięcie drzew i krzewów, a podejmowane na jego podstawie działania posiadają i zachowują przymiot legalności; 2) niedopełnienie obowiązku nasadzeń zastępczych przez adresata aktu powoduje powstanie po stronie organów obowiązku doprowadzenia do jego przymusowego wykonania.

\section{Słowa kluczowe}

Ochrona przyrody; nasadzenia zastępcze; zlecenie.

\section{ABSTRACT}

A resolution on replacement planting, understood as a replacement of extracted trees and bushes with other trees and bushes, constitutes an element of trees and bushes removal permit. A decision on incorporating this element into a permit is made discretionary by an administrative body issuing it. A normative construction used in the environmental law corresponds with a deeply grounded doctrine of administrative law, which is the concept of an order. An order constitutes an additional provision of an administrative decision, on the base of which an addressee of the decision is obliged to fulfil additional administrative responsibilities. Assuming that an obligation of replacement planting resulting from trees and bushes removal permit is considered to be an order, in its definition provided by doctrine of administrative law, it leads to two fundamental conclusions: 1) failure to comply with the obligation of replacement planting does not directly influence the effectiveness of the permit, and all actions taken on its ground are considered legal, 2) failure to comply with the obligation of replacement planting leads to an obligation on the part of an administrative body to cause its compulsory execution.

\section{Keywords}

2/2015 Nature conservation; replacement planting; order. 


\section{WPROWADZENIE}

Zezwolenie na usunięcie drzew i krzewów stanowi jeden z podstawowych instrumentów ochrony zadrzewień w prawie polskim. Ochrona ta, w myśl art. 2 Ustawy z dnia 16 kwietnia 2004 r. o ochronie przyrody ${ }^{1}$, polega na zachowaniu, zrównoważonym użytkowaniu oraz odnawianiu zasobów, tworów i składników przyrody, do których ustawodawca zalicza m.in. zieleń $\mathrm{w}$ miastach i wsiach oraz zadrzewienia. Jednym z elementów konstrukcji zezwolenia na usunięcie drzew i krzewów w prawie polskim jest instytucja nasadzeń zastępczych. Pod pojęciem tym rozumiem zastąpienie drzew i krzewów objętych zezwoleniem na usunięcie innymi drzewami i krzewami. Zgodnie z art. 83 ust. 3 u.o.p. wydanie zezwolenia na usunięcie drzew i krzewów może być uzależnione od przesadzenia drzew lub krzewów w miejsce wskazane przez wydającego zezwolenie albo zastąpienia ich innymi drzewami lub krzewami, w liczbie nie mniejszej niż liczba usuwanych drzew lub krzewów. O obowiązku dokonania nasadzeń zastępczych orzeka organ wydający zezwolenie na usunięcie drzew i krzewów. Obowiązek dokonania nasadzeń zastępczych nie ma charakteru samoistnego, a jego powstanie pozostaje $\mathrm{w}$ bezpośrednim związku z uprawnieniem do usunięcia drzew lub krzewów, wynikającym z udzielonego zezwolenia. W doktrynie prawa ochrony środowiska analiza istoty obowiązku nasadzeń zastępczych odnosi się przede wszystkim do problemu niedookreśloności przesłanek, jakimi powinien kierować się organ administracyjny przy jego nakładaniu, a - co się z tym wiąże - granic uznania administracyjnego w przedmiotowych sprawach oraz skutków niedopełnienia obowiązku nasadzeń zastępczych ${ }^{2}$. Przedmiotem niniejszego opracowania jest ustale-

1 Tekst jedn. Dz.U. z 2013 r., poz. 627 ze zm., zwana dalej ustawą o ochronie przyrody lub określana skrótem u.o.p.

2 B. Rakoczy, Usuwanie drzew i krzewów, Warszawa 2013, s. 73 i n.; G. Klimek, Nasadzenia zastępcze - wybrane problemy $w$ podejmowaniu decyzji, w: Prawne aspekty gospodarowania zasobami środowiska. Korzystanie z zasobów środowiska, red. B. Rakoczy, M. Szalewska, K. Karpus, Toruń 2014, s. 211 i n.; W. Radecki, Nasadzenia zastępcze przy usuwaniu drzew bez konieczności 
nie konstrukcji normatywnej obowiązku nasadzeń zastępczych jako elementu decyzji administracyjnej. Ustalenia te, w mojej ocenie, są niezbędne dla prowadzenia dalszych badań nad stosowaniem przyjętych w Ustawie o ochronie przyrody rozwiązań prawnych w zakresie ochrony drzew i krzewów.

\section{ISTOTA ZEZWOLENIA NA USUWANIE DRZEW I KRZEWÓW}

Zgodnie z art. 83 ust. u.o.p. usunięcie drzew lub krzewów $\mathrm{z}$ terenu nieruchomości może nastąpić, z zastrzeżeniem ust. 2 i $2 \mathrm{a}$ art. 83 u.o.p., po uzyskaniu zezwolenia wydanego przez wójta, burmistrza albo prezydenta miasta na wniosek posiadacza nieruchomości, za zgodą właściciela tej nieruchomości, bądź też na wniosek właściciela urządzeń, o których mowa w art. 49 $\S 1$ Kodeksu cywilnego - jeżeli drzewa lub krzewy zagrażają funkcjonowaniu tych urządzeń. Ustawodawca ograniczył w ten sposób sferę wolności jednostki w zakresie przysługujących jej praw rzeczowych do nieruchomości poprzez wprowadzenie wymogu uzyskania akceptacji organu administracji publicznej dla podejmowanych przez nią działań ukierunkowanych na korzystanie z przedmiotu przysługujących jej praw rzeczowych (elementy składowe nieruchomości). Ograniczenie wolności jednostki poprzez administracyjnoprawną reglamentację usuwania drzew i krzewów z terenu nieruchomości uzasadnione jest koniecznością ochrony interesu publicznego determinowanego przyjętym systemem dóbr i wartości ${ }^{3}$.

W doktrynie prawa administracyjnego wskazuje się, iż wymóg uzyskania zezwolenia administracyjnego stanowi technikę

ponoszenia opłat, „Nowe Zeszyty Samorządowe” 2006, nr 2, s. 56 i n.; K. Gruszecki, Realizacja zasady zrównoważonego rozwoju środowiska („nasadzenia zastępcze"), ZNSA 2007, nr 5-6, s. 37 i n.; J. Łukaszkiewicz, Nasadzenia zastępcze drzew $w$ miastach - główne problemy z decyzjami administracyjnymi, „Zrównoważony rozwój - zastosowania" 2013, nr 4, s. 28 i n.

2/2015 B. Rakoczy, op. cit., s. $21 \mathrm{i} \mathrm{n}$. 
prawodawczą, za pomocą której państwo realizuje trzy podstawowe funkcje: ochronną (nadzorczą), regulacyjną i sterującą ${ }^{4}$. Zezwolenia administracyjne zaliczane są do aktów uprawniających $^{5}$ i stanowią instytucje materialnego prawa administracyjnego, polegające na podejmowaniu przez organy administracji publicznej czynności umożliwiających jednostce przejawianie określonych zachowań, bez których zachowania takie byłyby prawnie niedopuszczalne ${ }^{6}$. Istotą typowego zezwolenia administracyjnego jest wiążące ustalenie niezaistnienia żadnej, dającej się oprzeć na obowiązującym prawie, przeszkody w podjęciu określonej działalności czy innego rodzaju zachowań ${ }^{7}$. Stopień zdeterminowania treści rozstrzygnięcia organu administracyjnego normą prawną, stanowiącą podstawę do wydania zezwolenia, uzasadnia rozróżnienie zezwoleń związanych i zezwoleń uznaniowych. W przypadku zezwoleń związanych przepis prawa w sposób jednoznaczny i definitywny określa przesłanki rozstrzygnięcia administracyjnego, wykluczając w tym zakresie jakiekolwiek luzy decyzyjne po stronie organu administracyjnego. Oznacza to, iż kryteria oceny (wartościowania) zamierzenia, na które zezwolenie ma być udzielone, określa ustawa bądź wydany na jej podstawie i w celu jej wykonania akt wykonawczy $^{8}$. Odmiennie kształtuje się sytuacja w przypadku tzw. zezwoleń uznaniowych, to jest takich, przy wydawaniu których dopełnienie zbioru kryteriów, od których zależy treść rozstrzygnięcia, pozostawiono dyskrecjonalnej władzy administracji publicznej. W ocenie D. Kijowskiego „istota i cel regulacji prawnych, przewidujących możliwość wydawania zezwoleń

4 Por. D. R. Kijowski, Uprawnienia administracyjne, w: System prawa administracyjnego, t. 7, Prawo administracyjne materialne, red. R. Hauser, Z. Niewiadomski, A. Wróbel, Warszawa 2012, s. 395; idem, Pozwolenia $w$ administracji publicznej. Studium z teorii prawa administracyjnego, Białystok 2000, s. $177 \mathrm{i} \mathrm{n.}$

5 J. Supernat, Instrumenty działania administracji publicznej. Studium z nauki administracji, Wrocław 2003, s. 54 i n.

6 Por. D. R. Kijowski, Uprawnienia administracyjne, s. 384; idem, Pozwolenia $w$ administracji publicznej, s. 39 i n.

7 D. R. Kijowski, Pozwolenia $w$ administracji publicznej, s. 301.

8 D. R. Kijowski, Uprawnienia administracyjne, s. 393. 
uznaniowych, polega na stworzeniu organom administrującym możliwości wyznaczania w każdej indywidualnej sytuacji zakresu negatywnych praw podmiotowych jednostki względem państwa lub innego podmiotu sprawującego władzę publiczną, bądź też określenia granic jej konstytucyjnych praw pozytywnych" . Szczegółowa analiza konstrukcji normatywnych, stanowiących podstawę udzielania zezwoleń, pozwoliła D. Kijowskiemu na wyodrębnienie w zbiorze zezwoleń uznaniowych dalszych podkategorii, do których Autor ten zalicza pozwolenia w pełni dyskrecjonalne, pozwolenia blankietowe, pozwolenia wyjątkowe (w tym dyspensy), pozwolenia wydawane w oparciu o pozytywną ocenę celowości zamierzonej działalności ${ }^{10}$. W ocenie J. Supernata z pozwoleniami w pełni dyskrecjonalnymi mamy do czynienia w przypadkach, w których przepisy prawa nie formułują żadnych wskazówek, którymi ma się kierować organ administracji publicznej przy rozstrzyganiu o udzieleniu lub odmowie udzielenia zezwolenia ${ }^{11}$. Wypowiedź tę należałoby sprecyzować, iż chodzi tu o brak wyraźnych i bezpośrednich wskazań ustawodawcy co do przesłanek udzielenia lub odmowy udzielenia zezwolenia. Jak słusznie bowiem zauważa D. Kijowski, „ustanowienie w demokratycznym państwie prawnym wymogu uzyskania zgody organu administracji publicznej na cokolwiek nie może być odczytywane jako udzielenie takiemu organowi upoważnienia do samowolnego rozstrzygania o tym, komu i kiedy taka zgoda będzie udzielona, a kto i kiedy uzyska decyzję odmowną"12. Treść rozstrzygnięcia organu administracji publicznej determinowana jest bowiem nie tylko treścią przepisu upoważniającego do podjęcia danej decyzji, ale również jego zgodnością z systemem prawa. Oznacza to, że także wówczas, gdy ustawodawca nie wskaże wprost, na jakich kryteriach ma zostać oparte rozstrzygnięcie, organ rozstrzygający sprawę musi zawsze móc wykazać, że-korzystając z danej kompetencji - użył jej zgodnie z celem i w granicach udzielonego upoważnienia,

9 Ibidem, s. 393.

10 D. R. Kijowski, Pozwolenia $w$ administracji publicznej, s. 75 i n.

11 J. Supernat, op. cit., s. 58.

12 D. R. Kijowski, Uprawnienia administracyjne, s. 392. 
wyznaczonych przez wszystkie przepisy prawa, które obiektywnie mają $\mathrm{w}$ danej sprawie zastosowanie ${ }^{13}$.

Przenosząc powyższe ustalenia na grunt Ustawy o ochronie przyrody, należy wskazać, iż konstrukcja zezwolenia na usunięcie drzew i krzewów oparta została na modelu zezwolenia uznaniowego ${ }^{14}$, zaliczanego - wg klasyfikacji przyjętej przez D. Kijowskiego - do zezwoleń w pełni dyskrecjonalnych. Teza ta wynika z faktu, iż przepisy regulujące obowiązek uzyskania przedmiotowego zezwolenia oraz kompetencje do jego wydania nie określają wprost przesłanek bądź też kryteriów rozstrzygnięcia podejmowanego przez organ administracyjny, pozostawiając każdorazowo jego ocenie zasadność udzielenie zezwolenia ${ }^{15}$. Nie oznacza to jednak, iż proces rozstrzygania sprawy,

13 Ibidem, s. 392.

14 Por. Wyrok Trybunału Konstytucyjnego z dnia 1 lipca 2014, SK 6/12, OTK-A z 2014, nr 7 poz. 68; B. Rakoczy, op. cit., s. 62.

15 Należy jednocześnie zastrzec, iż dookreślenie w tym przypadku zezwoleń przymiotnikiem uznaniowe nawiązuje do szerokiej koncepcji uznania administracyjnego utożsamianego z pojęciem dyskrecjonalnych działań administracji publicznej. Nie mamy tu do czynienie natomiast z uznaniem administracyjnym w ścisłym tego słowa znaczeniu, rozumianym wyłącznie jako prawna możliwość wyboru konsekwencji normy prawnej. Tak rozumiane uznanie administracyjne stanowi ostatni element procesu stosowania prawa administracyjnego, który następuje po dokonaniu subsumcji, a przed ostatecznym sformułowaniem treści aktu administracyjnego. Ciężar „uznaniowości” zezwolenia w stosunku do którego ustawodawca nie określił wprost przesłanek bądź też kryteriów jego wydania (odmowy wydania), przesunięty został natomiast na pozostawienie organom orzekającym pewnego „luzu” w ustaleniu hipotezy normy prawnej, przede wszystkim poprzez konieczność odwołania się do zasad ogólnych, klauzul generalnych czy pojęć niedookreślonych oraz oceny stanu faktycznego w kontekście tak zrekonstruowanej hipotezy normy prawnej. „Luz” ten odnosi się więc do etapu wykładni przepisów prawa oraz dokonania oceny stanu faktycznego. Organ w konkretnej sprawie musi dokonać ustalenia zakresu znaczeniowego, takich pojęć jak: interes publiczny, interes jednostki, zrównoważony rozwój, zrównoważone gospodarowanie zasobami przyrody oraz dokonać oceny stanu faktycznego w odniesieniu do tak ustalonej hipotezy. W przypadku ustalenia, iż planowane zamierzenie (usunięcie drzew lub krzewów) nie pozostaje w sprzeczności z zasadą zrównoważonego rozwoju czy zasadą zrównoważonego gospodarowania zasobami przyrody oraz brak jest innych przesłanek odmowy udzielenia zezwolenia (uzasadniony interes publiczny) organ jest zobowiązany do wydania zezwolenia na usunięcie drzew lub krzewów i w tym zakresie decyzja taka jest decyzją 
której przedmiotem jest udzielenie zezwolenia na usunięcie drzew i krzewów nie jest zdeterminowany przepisami prawa powszechnie obowiązującego i przebiega w oparciu o całkowicie swobodne uznanie organów administracji publicznej. Jak wskazano powyżej, również $\mathrm{w}$ przypadku zezwoleń $\mathrm{w}$ pełni dyskrecjonalnych obowiązkiem organów orzekających jest zapewnienie zgodności podejmowanych rozstrzygnięć z całym systemem norm prawnych obowiązujących w przedmiotowej sprawie oraz systemem prawnym jako całością. Szczególne znaczenie dla prawidłowej rekonstrukcji hipotezy normy prawnej w tym przypadku mieć będą zasady ogólne i to zarówno zasady ogólnosystemowe, w tym w szczególności zasady konstytucyjne (zasada zrównoważonego rozwoju, zasada ochrony prawa własności, zasada proporcjonalności), zasady właściwe dla danej gałęzi prawa (zasada zintegrowanej ochrony środowiska ${ }^{16}$, zasada reglamentacji, zasada uwzględniania interesu publicznego oraz słusznego interesu jednostki w procesie wydawania decyzji administracyjnych) oraz zasady przyjęte w samej Ustawie o ochronie przyrody (zasada zrównoważonego gospodarowania zasobami przyrody ${ }^{17}$, zasada zrównoważonego użytkowania różnorodności biologicznej).

W doktrynie prawa administracyjnego, oprócz rozróżnienia zezwoleń związanych i uznaniowych, dokonuje się również podziału na zezwolenia proste i zezwolenia złożone ${ }^{18}$. Zezwolenie proste stanowi rozstrzygnięcie organu wyłącznie co do kwestii, czy zgłoszone zamierzenie jest dopuszczalne i może być zrealizowane, czy też nie. Zezwolenie złożone natomiast pozytywnie kształtują prawa i obowiązki adresata aktu administracyjnego, nakazując lub zakazując określonych zachowań

związaną. Por. M. Mincer, Uznanie administracyjne, Toruń 1983 oraz powołane tam poglądy doktryny; M. Jaśkowska, Związanie decyzji administracyjnej ustawą, Toruń 1998, s. 139 i n.

16 Na temat zasad prawa ochrony środowiska zob. P. Korzeniowski, Zasady prawne ochrony środowiska, Łódź 2010.

17 Por. J. Ciechanowicz-McLean, w: Polskie prawo ochrony przyrody, red. J. Ciechanowicz-McLean, Warszawa 2006, s. 33-34; J. Sommer, w: Teoretyczne podstawy prawa ochrony przyrody, red. W. Radecki, Wrocław 2006, s. 100.

18 D. R. Kijowski, Pozwolenia w administracji publicznej, s. 80. 
podczas korzystania z wynikających z zezwolenia uprawnień. W przypadku zezwoleń złożonych orzeczenie o braku przeszkód podjęcia określonych działań jest uzupełnione poprzez: 1) wyznaczenie zakresu przedmiotowego, terytorialnego i czasowego udzielanych uprawnień; 2) ustanowienie warunków, od których spełnienia zależy możliwość rozpoczęcia dozwolonych działań lub zaistnienie których spowoduje utratę uprawnienia; 3) nałożenie obowiązków określonych zachowań podczas korzystania $\mathrm{z}$ ustalonych uprawnień ${ }^{19}$. Zakres orzeczenia wskazany w pkt 1 służy dookreśleniu treści uprawnienia i pozostaje $\mathrm{z}$ nim $\mathrm{w}$ nierozerwalnym związku. Elementy wskazane w pkt 2 i 3 stanowią natomiast tzw. klauzule dodatkowe aktu administracyjnego warunek i zlecenie. O ile pierwsza z nich (warunek) determinuje obowiązywanie aktu administracyjnego określonym w decyzji stanem faktycznym, o tyle druga (zlecenie) stanowi bezpośrednie źródło obowiązków skorelowanych z zasadniczą treścią aktu administracyjnego (w przypadku zezwolenia - uprawnieniem do podjęcia określonych działań). Ich cechą wspólną jest więc stymulowanie adresata aktu administracyjnego do zachowań uznanych przez ustawodawcę i organ administracyjny za pożądane w konkretnej sytuacji faktycznej i prawnej, przez co realizowana jest funkcja sterowania.

Dokonując analizy istoty zezwolenia na usunięcie drzew i krzewów należy wskazać, iż przepisy Ustawy o ochronie przyrody expressis verbis dopuszczają możliwość zawarcia w zezwoleniu na usunięcie drzew i krzewów klauzuli dodatkowej wyrażającej obowiązek przesadzenia drzewa lub dokonania nasadzeń zastępczych. Zgodnie z art. 83 ust. 3 u.o.p. wydanie zezwolenia na usunięcie drzew i krzewów może być uzależnione od przesadzenia drzew lub krzewów w miejsce wskazane przez wydającego zezwolenie albo zastąpienia ich innymi drzewami lub krzewami, w liczbie nie mniejszej niż liczba usuwanych drzew lub krzewów. Wykładnia językowa tego przepisu skłania przedstawicieli doktryny do zajęcia stanowiska, iż art. 83 ust. 3 u.o.p. stanowi podstawę wprowadzenia do zezwolenia na usunięcie drzew lub krzewów warunku. Pojęciem decyzji

19 D. R. Kijowski, Uprawnienia administracyjne, s. 392. 
warunkowej w odniesieniu do zezwolenia na usunięcie drzew lub krzewów zawierającego obowiązek przesadzenia lub nasadzeń zastępczych posługuje się, m.in.: B. Rakoczy ${ }^{20}$, K. Gruszec$\mathrm{ki}^{21}$ oraz G. Klimek ${ }^{22}$. W sposób jednoznaczny na konstrukcję warunku wskazuje również W. Radecki stwierdzając, iż w przypadku niespełnienia warunku dokonania nowych nasadzeń zezwolenie wygasa, a wnioskodawcę należy potraktować, jak gdyby usunął drzewa bez zezwolenia i nałożyć na niego karę pieniężną ${ }^{23}$. Wyrażone $\mathrm{w}$ doktrynie prawa ochrony środowiska poglądy, co do charakteru zastrzeżenia w zezwoleniu na usunięcie drzew lub krzewów, obowiązku nasadzeń zastępczych skłaniają do polemiki odnoszącej się do istoty i skutków tegoż zastrzeżenia.

\section{WARUNEK I ZLECENIE JAKO KLAUZULE DODATKOWE AKTU ADMINISTRACYJNEGO}

W doktrynie prawa administracyjnego powszechnie wskazuje się na możliwość występowania w aktach administracyjnych pewnych elementów określanych jako klauzule dodatkowe aktu administracyjnego ${ }^{24}$, elementy dodatkowe decyzji ${ }^{25}$,

20 B. Rakoczy, op. cit., s. 74 i n.

${ }^{21}$ K. Gruszecki, Zezwolenia na usunięcie drzew i krzewów, Lex 2010, wer. el.

22 G. Klimek, op. cit., s. 215.

23 W. Radecki, op. cit., s. 56 i n. Pogląd wyrażony przez W. Radeckiego spotkał się z pełną aprobatą K. Gruszeckiego, zob. Zezwolenia na usunięcie drzew i krzewów oraz Realizacja zasady zrównoważonego rozwoju środowiska, s. 40. Z kolei B. Rakoczy przyjmuje, iż niespełnienie warunku przesadzenia lub nasadzenia drzew (krzewów) skutkuje wygaśnięciem zezwolenia ze skutkiem wstecznym, z czym nie można jednak automatycznie i bezpośrednio łączyć obowiązku uiszczenia administracyjnej kary pieniężnej. B. Rakoczy, Usuwanie drzew i krzewów, s. 76.

24 E. Ochendowski, Prawo administracyjne. Część ogólna, Toruń 2013, s. 211; T. Dziuk, Klauzule dodatkowe decyzji administracyjnej, „Casus” 2010, nr 1 , s. 16 i n.

25 J. Zimmermann, Prawo administracyjne, Warszawa 2012, s. 331. 
klauzule uboczne ${ }^{26}$ czy elementy uzupełniające (akcesoryjne) ${ }^{27}$. Wśród klauzul (elementów) tych wyróżnia się m.in. warunek i zlecenie. Cechą wspólną wszystkich klauzul dodatkowych decyzji administracyjnej jest dopuszczalność ich zastrzeżenia wyłącznie w przypadku wyraźnego udzielenia organom orzekającym kompetencji w tym zakresie, co wynika z zasady legalności i praworządności.

Warunek stanowi element dodatkowy aktu administracyjnego, którego istota sprowadza się do możliwości uzależnienia wywołania określonych skutków prawnych (zaktualizowania bądź wygaśnięcia obowiązku czy uprawnienia ustalonego aktem) od zdarzenia przyszłego i niepewnego, w tym sensie, że nie można stanowczo przesądzić o tym, kiedy i czy w ogóle zdarzenie to nastąpi ${ }^{28}$. W związku z powyższym przyjmuje się, iż jako warunek w prawie administracyjnym (w analizowanym tu znaczeniu) może być traktowane wyłącznie takie oświadczenie woli organu administracyjnego - dodane do decyzji jako jej postanowienie dodatkowe i pozostające $\mathrm{z}$ nią w ścisłym związku, na podstawie którego moc wiążąca w czasie decyzji (rozpoczęcie lub ustanie jej obowiązywania) zostaje uzależniona od zdarzenia przyszłego i niepewnego ${ }^{29}$. Jedną z podstawowych typologii warunków, opartą o kryterium skutków wywołanych ziszczeniem się zdarzenia przyszłego i niepewnego, jest rozróżnienie warunku zawieszającego i rozwiązującego ${ }^{30}$. Warunek zawieszający stanowi element dodatkowy aktu administracyjnego, który od zdarzenia przyszłego i niepewnego uzależnia rozpoczęcie obowiązywania tego aktu (a dokładnie tej jego czę-

26 T. Woś, Termin, warunek $i$ zlecenie $w$ prawie administracyjnym, „Państwo i Prawo" 1994, nr 6, s. 23.

27 K. Ziemski, Indywidualny akt administracyjny - jego istota, w: System prawa administracyjnego, t. 5, Prawne formy działania administracji, red. R. Hauser, Z. Niewiadomski, A. Wróbel, Warszawa 2013, s. 201 i n.

28 Ibidem, s. 203 i n.

29 T. Woś, Termin, warunek $i$ zlecenie $w$ prawie administracyjnym, s. 28.

30 W literaturze przedmiotu spotyka się ponadto podział warunków ze względu na okoliczności, od których zależy byt zdarzenia przyszłego i niepewnego, na warunki kauzalne, potestatywne i mieszane oraz dodatnie i ujemne. T. Dziuk, op. cit., s. 18. 
ści, która stanowi rozstrzygnięcie istoty sprawy). Zastrzeżenie w decyzji warunku zawieszającego powoduje, iż moc wiążąca tego aktu zostaje niejako zawieszona do czasu spełnienia warunku, co w przypadku aktów uprawniających uniemożliwia korzystanie z przyznanych uprawnień do czasu ziszczenia się zdarzenia przyszłego i niepewnego stanowiącego warunek. Warunek rozwiązujący stanowi natomiast zdarzenie przyszłe i niepewne, którego ziszczenie powoduje ustanie skutków aktu administracyjnego. Zastrzeżenie w decyzji warunku rozwiązującego spowoduje, iż jego spełnienie wywoła ustanie mocy wiążącej tej decyzji (jej wygaśnięcie). Przedstawiciele doktryny prawa administracyjnego zgodnie podkreślają wyjątkową niekonsekwencję ustawodawcy w posługiwaniu się terminem „warunek", ograniczającą możliwość stosowania wykładni językowej dla prawidłowego określenia dopuszczalności zastosowania warunku jako klauzuli dodatkowej aktu administracyjnego bądź też dla ustalenia, że dopuszczona przez ustawodawcę klauzula dodatkowa jest $\mathrm{w}$ swej istocie warunkiem $\mathrm{w}$ podanym wyżej znaczeniu ${ }^{31}$.

Odmiennym od warunku elementem dodatkowym aktu administracyjnego jest zlecenie. Istotą klauzuli zlecenia jest spowodowanie pewnego zdarzenia poprzez nałożenie na adresata aktu określonego obowiązku pozostającego w ścisłym związku ze stwierdzonymi aktem administracyjnym skutkami prawnymi (np. przyznanymi uprawnieniami). Wykonanie (niewykonanie) zlecenia nie wpływa bezpośrednio na obowiązywanie aktu administracyjnego czy też jego skuteczność, lecz stanowi źródło obowiązku pozostającego w bezpośrednim związku z jego zasadniczą treścią (rozstrzygnięciem). Jak zauważa T. Woś, zlecenie nie zawiesza skuteczności decyzji, do której zostało dodane, nie odracza możliwości jej wykonania, ale zobowiązuje, zmusza adresata decyzji do jej wykonania zgodnie ze zleceniem ${ }^{32}$. Autor ten różnicę pomiędzy warunkiem a zleceniem ujmuje w następującą formułę: dla warunku

31 Por. T. Woś, Termin, warunek $i$ zlecenie $w$ prawie administracyjnym, s. 27 i n.; K. Ziemski, op. cit., s. 204.

32 Ibidem, s. 31. 
obowiązuje zasada - kiedy zrobisz to i to, wolno ci zrobić coś innego, natomiast dla zlecenia - wolno ci coś, ale musisz zrobić to $\mathrm{i}$ to $^{33}$. Istota zlecenia skłoniła przedstawicieli nauki prawa administracyjnego do postawienia tezy o możliwości uznania zlecenia za odrębny, dodatkowy akt administracyjny ${ }^{34}$, określany jako niesamoistny (akcesoryjny) akt administracyjny ${ }^{35}$. Akcesoryjność tego aktu wyraża się w ścisłym jego związku z aktem podstawowym (np. zezwoleniem). Zależność ta wyklucza możliwość nałożenia na adresata obowiązków w oderwaniu od treści rozstrzygnięcia aktu podstawowego (np. przyznania uprawnień, udzielenia zezwolenia). Uznanie istoty zlecenia jako źródła obowiązku administracyjnoprawnego, zdeterminowanego zasadniczym rozstrzygnięciem organu administracyjnego (w szczególności przyznaniem uprawnienia), uzasadnia tezę o dopuszczalności zastosowania środków przymuszających do wykonania tego obowiązku o charakterze egzekucyjnym lub sankcyjnym ${ }^{36}$. O ile jednak obowiązki administracyjne co do zasady mogą być egzekwowane poprzez system środków egzekucyjnych zastrzeżonych dla postępowania egzekucyjnego $\mathrm{w}$ administracji, o tyle zastosowanie sankcji administracyjnych wymaga każdorazowo wyraźnej podstawy prawnej. Szczególną sankcją zastrzeżoną, w sposób ogólny, na wypadek uchylania się adresata aktu administracyjnego od obowiązku wynikającego z zawartego w tym akcie zlecenia jest, uregulowana w art. $162 \S 2$ k.p.a., dopuszczalność uchylenia przez organ administracji publicznej tego aktu. Oznacza to, że - w przeciwieństwie do warunku - sam fakt wykonania lub niewykonania zlecenia nie wywołuje bezpośrednich skutków w zakresie obowiązywania aktu administracyjnego zawierającego zlecenie, a jedynie stanowi podstawę podjęcia przez organ administracji publicznej rozstrzygnięcia co do dalszego obowiązywania tego

33 T. Woś, Moc wią̇̇aca aktów administracyjnych w czasie, Warszawa 1978, s. 189.

34 E. Ochendowski, op. cit., s. 212.

35 K. Ziemski, op. cit., s. 205.

36 Por. E. Ochendowski, op. cit.; s. 213, T. Woś, Moc wiążaca aktów administracyjnych $w$ czasie, s. 189; K. Ziemski, op. cit., s. 205. 
aktu. Rozstrzygnięcie to jest podejmowane w odniesieniu do wszechstronnie zbadanych okoliczności sprawy, przy uwzględnieniu istoty samego zlecenia oraz zasadniczej treści aktu administracyjnego zawierającego zlecenie.

Analiza obowiązujących przepisów prawa pozwala przyjąć, iż ustawodawca zasadniczo nie posługuje się wprost pojęciem zlecenia dla określenia konstrukcji normatywnej, której cechy odpowiadają przyjętej na gruncie doktryny prawa administracyjnego istocie zlecenia. W ocenie K. Ziemskiego w praktyce prawodawczej najczęściej zastrzeżenie zlecenia następuje w sposób sugerujący, że do czynienia mamy w danej sytuacji $\mathrm{z}$ warunkiem ${ }^{37}$. Dlatego też należy w pełni zgodzić się z T. Wosiem, iż dla rozróżnienia obu tych instytucji prawnych (warunku i zlecenia) zasadnicze znaczenie powinno mieć ustalenie, czy skuteczność oświadczenia woli organu administracyjnego zawartego w decyzji administracyjnej uzależniona jest od nadejścia faktu określonego jako warunek (lub jakkolwiek inaczej), czy też raczej spowodowania tego faktu organ oświadczający wolę może żądać38.

\section{CHARAKTER NORMATYWNY OBOWIĄZKU NASADZEŃ ZASTĘPCZYCH}

Poczynione ustalenia doktrynalne pozwalają dokonać oceny konstrukcji obowiązku nasadzeń zastępczych jako elementu akcesoryjnego zezwolenia na usunięcie drzew lub krzewów. Jak już wskazano powyżej, w doktrynie prawa ochrony środowiska przyjmuje się, iż zastrzeżenie w decyzji zezwalającej na usunięcie drzew lub krzewów, obowiązku nasadzeń zastępczych stanowi warunek, którego niedopełnienie powoduje wygaśnięcie przedmiotowego zezwolenia. Powstaje w związku z tym pytanie, czy rzeczywiście istota obowiązku nasadzeń zastępczych odpowiada konstrukcji warunku jako klauzuli dodat-

38 T. Woś, Moc wiążąca aktów administracyjnych w czasie, s. 190. 
kowej aktu administracyjnego, zgodnie z przyjętym na gruncie prawa administracyjnego rozumieniem tej instytucji. Kluczową kwestią jest w tym przypadku ustalenie, czy ratio legis instytucji nasadzeń zastępczych stanowi zależność podejmowanych w tym zakresie działań adresata aktu administracyjnego i obowiązywania tego aktu w sferze uprawnień z niego wynikających. Zakładając, iż nasadzenia zastępcze stanowią warunek zawieszający zezwolenia na usunięcie drzew lub krzewów, należałoby stwierdzić, że w sytuacji takiej zezwolenie nie wywołuje skutków prawnych, w zakresie określonych w nim uprawnień, do czasu realizacji warunku, a więc dokonania nasadzeń zastępczych. Oznacza to, iż nasadzenie zastępcze ma w tym przypadku charakter uprzedni w stosunku do prawnej dopuszczalności skorzystania z przyznanych uprawnień usunięcia drzew lub krzewów. Uprawnienia te zostają „uaktywnione” poprzez spełnienie warunku zawieszającego. O ile konstrukcja taka jest dopuszczalna z teoretycznego punktu widzenia, o tyle, w mojej ocenie, nie odpowiada społeczno-gospodarczej istocie zezwolenia na usunięcie drzew lub krzewów oraz obarczona jest ryzykiem zarzutu niekonstytucyjności w związku z naruszeniem zasady proporcjonalności. Przyjęcie koncepcji warunku zawieszającego oznaczałoby faktyczne oderwanie obowiązku nasadzeń zastępczych od procesu wykonania uprawnienia do usunięcia drzew lub krzewów. Nasadzenia zastępcze stałyby się $\mathrm{w}$ istocie quasi-przesłanką nabycia tego uprawnienia (w momencie spełnienia warunku zezwolenie zaczęłoby obowiązywać), co w konsekwencji mogłoby, przynajmniej hipotetycznie, prowadzić do sytuacji, w której poniesienie ciężaru nasadzeń zastępczych nie wiązałoby się $\mathrm{z}$ wykonaniem uprawnień (po uzyskaniu zezwolenia, w ujęciu materialnym, adresat odstąpił od jego realizacji).

Odnosząc się do koncepcji nasadzeń zastępczych jako warunku rozwiązującego, należałoby na samym wstępie przyjąć, iż warunkiem tym $\mathrm{w}$ takim przypadku jest nie samo nasadzenie, ale jego faktyczny brak. Konstrukcja tego warunku opierałaby się na regule: jeżeli adresat zezwolenia nie dokona nasadzeń zastępczych, zezwolenie wygasa. Analiza dorobku doktryny prawa ochrony środowiska wskazuje, iż takie wła- 
śnie zapatrywanie na istotę nasadzeń zastępczych dominuje ${ }^{39}$. W tym miejscu należy wskazać, iż koncepcja warunku rozwiązującego, jako klauzuli dodatkowej aktu administracyjnego, zakłada, iż akt ten obowiązuje zarówno w sensie procesowym, jak i materialnym (wywołuje skutki prawne) od momentu jego wydania, a ziszczenie się zawartego w tym akcie warunku „unicestwia", wygasza go. Wygaśnięcie aktu administracyjnego następuje z mocy samego prawa, w momencie w którym ziścił się warunek wskazany w akcie. Określona w art. 162 § 1 pkt 2 k.p.a. kompetencja organu administracyjnego do stwierdzenia wygaśnięcia aktu administracyjnego upoważnia go do wydania decyzji deklaratoryjnej, potwierdzającej ${ }^{40}$. Organ orzekający na podstawie art. $162 \S 1$ k.p.a. nie wygasza decyzji administracyjnej (w ujęciu materialnym), a jedynie w sposób wiążący ustala jej wygaśnięcie w przeszłości ( $w$ momencie ziszczenia się warunku). Decyzja ta wywiera skutki ex nunc, ale nie od momentu wydania samego zezwolenia, lecz od momentu ziszczenia się warunku rozwiązującego. Oznacza to, iż od momentu wydania zezwolenia do jego wygaśnięcia adresat aktu administracyjnego legitymowany jest do wykonywania przyznanych mu uprawnień, a więc podejmowania działań, na które uzyskał przyzwolenie władzy publicznej (w analizowanym przypadku usunięcie drzew lub krzewów). Uprawnienia wynikające z zezwolenia na usunięcie drzew i krzewów mają charakter jednorazowy. Zakres tych uprawnień wyczerpuje się poprzez podjęcie określonej, pojedynczej czynności - usunięcia konkretnego drzewa. W doktrynie prawa administracyjnego słusznie wskazuje się, iż uczynienie zadość prawu, jeżeli jego przedmiotem było jednorazowe zachowanie, stanowi zdarzenie skutkujące wygaśnięciem decyzji administracyjnej w ujęciu materialnym ${ }^{41}$. Tak jak obowiązek

39 Por. W. Radecki, op. cit., s. 56; B. Rakoczy, op. cit., s. 74; K. Gruszecki, Zezwolenia na usunięcie drzew i krzewów, op. cit.; G. Klimek, op. cit., s. 215.

40 Por. T. Kiełkowski, Nabycie prawa na mocy decyzji administracyjnej, Warszawa 2012, s. 355 i n.; M. Kamiński, Materialnoprawne wygaśnięcie i proceduralne stwierdzenie wygaśnięcia mocy obowiązującej decyzji administracyjnej, w: Kodyfikacja postępowania administracyjnego. Na 50-lecie K.P.A, red. J. Niczyporuk, Lublin 2010, s. 259 i n.

${ }^{41}$ Por. T. Kiełkowski, op. cit., s. 355; J. Zimmermann, op. cit., s. 333. 
administracyjny wygasa na skutek jego spełnienia, tak i uprawnienie, o ile nie jest uprawnieniem ciągłym, wygasa na skutek jego realizacji (zrealizowania przyznanych świadczeń, usunięcie drzewa). Oznacza to, że w przypadku zezwolenia na usunięcie drzewa, zawarte $\mathrm{w}$ tym zezwoleniu uprawnienie wygasa na skutek jego realizacji i późniejsze zdarzenia faktyczne bądź prawne nie mają istotnego znaczenia dla tego stanu (nie może wygasnąć coś co wcześniej już wygasło).

Przedstawione argumenty, w mojej ocenie, przemawiają za odrzuceniem koncepcji warunku rozwiązującego dla ustalenia istoty obowiązku nasadzeń zastępczych. Argumenty te można dodatkowo wzmocnić stwierdzeniem, iż - przyjmując że warunkiem rozwiązującym jest brak nasadzeń zastępczych - warunek ten istnieje (jest ziszczony) już od momentu wydania zezwolenia, co w zasadzie niweczy całą konstrukcję warunku rozwiązującego. Uważam więc, iż obowiązek nasadzeń zastępczych nie stanowi warunku zezwolenia na usunięcie drzew lub krzewów $\mathrm{w}$ przyjętym w doktrynie prawa administracyjnego znaczeniu. Istotą wprowadzenia obowiązku nasadzeń zastępczych nie jest ograniczenie w czasie obowiązywania zezwolenia na usunięcie, lecz skorelowanie uprawnienia do usunięcia drzew lub krzewów z obowiązkiem nasadzeń zastępczych. Istoty tej nie sposób odnaleźć ani w regule „uzyskasz uprawnienie jeśli dopełnisz obowiązku” (warunek zawieszający), ani też w regule „utracisz uprawnienie jeśli nie dopełnisz obowiązku" (warunek rozwiązujący).

Adekwatnym, w mojej ocenie, dla odzwierciedlenia relacji pomiędzy zezwoleniem na usunięcie drzew i krzewów (w ujęciu materialnym) a obowiązkiem nasadzeń zastępczych, jest stwierdzenie „możesz usunąć ale musisz nasadzić”. Reguła ta w pełni odpowiada formule zlecenia jako klauzuli dodatkowej aktu administracyjnego. Poprzez zamieszczenie w zezwoleniu na usunięcie drzew i krzewów obowiązku nasadzeń zastępczych organ orzekający „wiąże” uprawnienie do usunięcia drzew i krzewów z obowiązkiem dokonania nasadzeń zastępczych. Więź ta nie odnosi się do ograniczenia w czasie obowiązywania udzielonego zezwolenia, lecz do powstania po stronie adresata zezwolenia obowiązku uwarunkowanego skorzystaniem z przyznanych 
uprawnień. Z momentem, w którym adresat zezwolenia skorzystał z przyznanych mu uprawnień, obciąża go obowiązek dokonania nasadzeń zastępczych. Obowiązek ten jest typowym obowiązkiem administracyjnym ${ }^{42}$, za który uznaje się skierowany do jednostki nakaz określonego zachowania, wynikający z polecenia organu władzy publicznej, dotyczący spraw regulowanych normami prawa administracyjnego, wydany w zakresie jego kompetencji i we właściwej formie ${ }^{43}$. Koncepcja zlecenia dla obowiązku nasadzeń zastępczych w pełni odpowiada zarówno realizacji kompensacyjnej funkcji tegoż obowiązku ${ }^{44}$, jak i funkcji sterującej zezwoleń administracyjnych. Poprzez nakładanie obowiązku nasadzeń zastępczych organ administracyjny dysponuje skutecznym środkiem kompensowania ubytków w zasobach przyrody, powstających na skutek usuwania drzew i krzewów, w sposób odpowiadający ogólnej zasadzie zrównoważonego rozwoju oraz zasadzie szczegółowej zrównoważonego gospodarowania zasobami przyrody. Przyjęcie, iż wynikający z zezwolenia na usunięcie drzew lub krzewów, obowiązek nasadzeń zastępczych stanowi zlecenie, w znaczeniu przyjętym w doktrynie prawa administracyjnego, prowadzi do dwóch zasadniczych wniosków: 1) niedopełnienie obowiązku nasadzeń zastępczych nie ma bezpośredniego wpływu na skuteczność (obowiązywanie) zezwolenia na usunięcie drzew i krzewów, a podejmowane na jego podstawie działania posiadają i zachowują przymiot legalności; 2) niedopełnienie obowiązku nasadzeń zastępczych przez adresata aktu powoduje powstanie po stronie organów obowiązku doprowadzenia do jego przymusowego wykonania.

42 Na temat obowiązku administracyjnego zob. P. Szreniawski, Obowiązek $w$ prawie administracyjnym, Lublin 2014, s. 24 i n.

43 Por. P. Przybysz, Obowiązek administracyjny - pojęcie, rodzaje, konkretyzacja, „Organizacja-Metody-Technika” 1990, nr 8-9, s. 14; L. Klat-Wertelecka, Niedopuszczalność egzekucji administracyjnej, Wrocław 2009, s. 153.

${ }_{44}$ Por. K. Gruszecki, Realizacja zasady zrównoważonego rozwoju środowiska, s. 39. 


\section{UWAGI KOŃCOWE}

Zlecenie, jako klauzula dodatkowa aktu administracyjnego, jest uznaną na gruncie prawa administracyjnego konstrukcją normatywną umożliwiającą kreowanie złożonych stosunków administracyjnoprawnych, w ramach których przysługujące stronie tego stosunku uprawnienia zostają połączone z ciążącymi na niej obowiązkami, pozostającymi w bezpośrednim związku z wykonywaniem tych uprawnień. Konstrukcja ta znajduje szerokie zastosowanie w przypadku tzw. zezwoleń złożonych, to jest takich, w których oprócz rozstrzygnięcia kwestii dopuszczalności podejmowania prze jednostkę określonych działań, sformułowane zostają również obowiązki określonych zachowań podczas korzystania z ustalonych uprawnień ${ }^{45}$. Jak zauważa D. Kijowski, w takich przypadkach można stwierdzić, iż dochodzi w nich do określenia zezwoleniem sposobu korzystania z przysługujących jednostce praw i wolności ${ }^{46}$. Konstrukcja zlecenia jest, w mojej ocenie, adekwatnym wzorcem oceny rozwiązań prawnych przyjętych w Ustawie o ochronie przyrody w zakresie nasadzeń zastępczych. Przepis art. 83 ust. 3 u.o.p. stanowi podstawę prawną, skonkretyzowanego w zezwoleniu na usunięcie drzew lub krzewów, obowiązku administracyjnego stanowiącego nakaz dokonania nasadzeń zastępczych w przypadku skorzystania z przyznanych uprawnień. Obowiązek ten ma charakter komplementarny w stosunku do uprawnień zawartych w zezwoleniu. Nie stanowi on warunku w znaczeniu techniczno-prawnym, gdyż nie oddziałuje w bezpośredni sposób na obowiązywanie zezwolenia w czasie. Jego istoty należy poszukiwać $\mathrm{w}$ wynikającej z zasady zrównoważonego gospodarowania zasobami przyrody, powinności zrekompensowania in natura uszczerbku przyrodniczego spowodowanego usunięciem drzew lub krzewów. Ustalenie, iż konstrukcja obowiązku nasadzeń zastępczych, o których mowa w art. 83 ust. 3 u.o.p., odpowiada istocie zlecenia ma zasadnicze znaczenie dla analizy

45 D. R. Kijowski, Uprawnienia administracyjne, s. 392.

46 Ibidem, s. 392. 
skutków prawnych niedopełnienia tych obowiązków oraz związanych z tym kompetencji organów administracji publicznej.

\section{BIBLIOGRAFIA}

Ciechanowicz-McLean J., w: Polskie prawo ochrony przyrody, red. J. Ciechanowicz-McLean, Warszawa 2006.

Dziuk T., Klauzule dodatkowe decyzji administracyjnej, „Casus” 2010, nr 1.

Gruszecki K., Realizacja zasady zrównoważonego rozwoju środowiska („nasadzenia zastępcze”), ZNSA 2007, nr 5-6.

Gruszecki K., Zezwolenia na usunięcie drzew i krzewów, Lex 2010, wer. el.

Jaśkowska M., Związanie decyzji administracyjnej ustawa, Toruń 1998.

Kamiński M., Materialnoprawne wygaśnięcie i proceduralne stwierdzenie wygaśnięcia mocy obowiązującej decyzji administracyjnej, w: Kodyfikacja postępowania administracyjnego. Na 50-lecie K.P.A, red. J. Niczyporuk, Lublin 2010.

Kiełkowski T., Nabycie prawa na mocy decyzji administracyjnej, Warszawa 2012.

Kijowski D. R., Pozwolenia $w$ administracji publicznej. Studium z teorii prawa administracyjnego, Białystok 2000.

Kijowski D. R., Uprawnienia administracyjne, w: System prawa administracyjnego, t. 7, Prawo administracyjne materialne, red. R. Hauser, Z. Niewiadomski, A. Wróbel, Warszawa 2012.

Klat-Wertelecka L., Niedopuszczalność egzekucji administracyjnej, Wrocław 2009.

Klimek G., Nasadzenia zastępcze - wybrane problemy w podejmowaniu decyzji, w: Prawne aspekty gospodarowania zasobami środowiska. Korzystanie z zasobów środowiska, red. B. Rakoczy, M. Szalewska, K. Karpus, Toruń 2014.

Korzeniowski P., Zasady prawne ochrony środowiska, Łódź 2010.

Łukaszkiewicz J., Nasadzenia zastępcze drzew w miastach - główne problemy z decyzjami administracyjnymi, „Zrównoważony rozwój zastosowania" 2013, nr 4.

Mincer M., Uznanie administracyjne, Toruń 1983.

Ochendowski E., Prawo administracyjne. Część ogólna, Toruń 2013.

Przybysz P., Obowiązek administracyjny - pojecie, rodzaje, konkretyzacja, „Organizacja-Metody-Technika” 1990, nr 8-9. 
Radecki W., Nasadzenia zastępcze przy usuwaniu drzew bez konieczności ponoszenia optat, „Nowe Zeszyty Samorządowe” 2006, nr 2.

Rakoczy B., Usuwanie drzew i krzewów, Warszawa 2013.

Sommer J., w: Teoretyczne podstawy prawa ochrony przyrody, red. W. Radecki, Wrocław 2006.

Supernat J., Instrumenty działania administracji publicznej. Studium z nauki administracji, Wrocław 2003.

Szreniawski P., Obowiązek w prawie administracyjnym, Lublin 2014.

Woś T., Moc wiąż̨ca aktów administracyjnych $w$ czasie, Warszawa 1978.

Woś T., Termin, warunek $i$ zlecenie $w$ prawie administracyjnym, „Państwo i Prawo" 1994, nr 6.

Ziemski K., Indywidualny akt administracyjny - jego istota, w: System prawa administracyjnego, t. 5, Prawne formy działania administracji, red. R. Hauser, Z. Niewiadomski, A. Wróbel, Warszawa 2013.

Zimmermann J., Prawo administracyjne, Warszawa 2012.

Kontakt e-mail:

szalew@law.umk.pl 